\title{
The Unique Things of Gifted Children Development
}

\author{
Syari Yuliana \\ Universitas Pendidikan Indonesia \\ Bandung, Indonesia \\ Syariyuliana12@student.upi.edu
}

\begin{abstract}
Gifted children have an over excitability (superstimulatibility) development in the growing aspect of growth. The purpose of this study is to obtain a picture of the development of gifted children from five aspects of development namely: cognitive, motor, social, emotional, language and moral ethics. Thus, the unique things of the five developmental aspects of the gifted children will be known. Using descriptive method of qualitative approach, this research explores the development data of four gifted participants through observation, interview and documentation. Subjects studied in this study were four boys who were in grade 6 elementary school acceleration class. In this article it is shown that each subject has his/her own uniqueness in the five aspects of development. There are standing out and unique things found in the development of the subjects such as the development of aspects of language that precede chronological age, and so forth. Gifted children develop in extremely sensitive (extreme) conditions in some areas and are unique in every aspect of their developments.
\end{abstract}

Keywords-Development, uniqueness, gifted children.

\section{INTRODUCTION}

The scientific literature shows that gifted children usually do not experience many difficulties to be in a group than children of his age ([1], [2]). However, talent seems to add to the complexity of individual development; This implies that gifted children face unique developmental problems ([3], [4], [2], [5]). Gifted children have unique developmental needs, especially in the social and educational fields [6]. For this reason, [5] and others argue that gifted children include special needs children's populations. Some literature also reveal the uniqueness of gifted children development so that parents can know that gifted children develop uniquely as intensity increases, perfectionism, or difficulty in building social relationships with peers [7]. Results of field studies conducted in one primary school showed one child who was arguing with his teacher about a mathematical formula. He insisted on his argument. Before the teacher showed evidence of some books, he did not believe. In addition, the subject's grammar when arguing with his teacher looked like he was at the same level as the teacher. He also debated his teacher in a polite way. This phenomenon shows that there is a uniqueness of aspects of the development of the subject, both positive and negative uniqueness. Therefore, this study aims to obtain a picture of the development of gifted children from five aspects of development i.e. cognitive, motor, social emotion, language and moral ethics, so the unique things of the five aspects of the development of gifted children will be known.

\section{MethOD}

The research approach was qualitative. Subjects studied in this study were four boys who were in grade 6 elementary school acceleration class. Their initial names were: Bz, Ry, Kl, and $\mathrm{Wd}$. The subjects of the research subjects became the main informants in the collection of research data. The research techniques used in this research were: observation to observe the five aspects of children development, interviews the subjects, classroom teachers and classmates to obtain objective data about the views of teachers and classmates on the five aspects of subject development, and strengthened through documentation studies on the results of children work and documentation studies that can support information about children development. Observation results, interviews and documentation studies were analyzed qualitatively which generated information - information about the uniqueness in the development of gifted children. The process of data analysis was done through data reduction, data presentation and conclusion and data verification.

This research used descriptive quantitative method. The study was conducted in one of the junior high schools in Bandung that received students with hearing impairment studying together with regular students in the same class. Data collection technique was done by filling out questionnaires by regular students. Twenty regular students were selected by random sampling in two different classes, where there were students with hearing impairment there. To complete the data, the researchers conducted observations and interviews related to the regular students' responses during the learning process in inclusive classes. The subjects of the interview were chosen by purposive sampling technique. Data analysis was done by descriptive analytic.

\section{RESULT AND DISCUSSION}

Gifted children develop in extremely sensitive (extreme) conditions in some areas and are unique in every aspect of their development. The uniqueness of the cognitive aspect of the four subjects is that their cognitive development has reached formal operational stage with their new age eleven years. Their cognitive developmental aspect is superior to their peers. From the information gained from the classroom teachers about their IQ test results, these four subject's IQ was 130. A special 
intelligent child has an IQ score of 125 or 130 and above [8]. These four subjects had a high curiosity in which he would not receive the knowledge and information that the teacher gave away on subjects they liked. The ability to think the idealists of the four subjects can be seen from their firm stance since they have their own reasons with their opinions and answers. This phenomenon is similar to research conducted by [9] who mentioned that they are perfectionist; tend to be very idealistic, and looking for what is fair at an early age. The uniqueness of the motor development of the four subjects was shown by two people among the four subjects who liked less activities involving motor, especially rough motor. $\mathrm{Bz}$ was willing to be rated low in order to avoid activities involving motorics such as taking too long, not liking exercising. While Ry was forced to follow activities involving motorics because he felt if he did not do them he would have an impact on his performance then he was forced to do so. Moreover, two other subjects had the same motor development with children their age. In term of the uniqueness of emotional social development, of the four subjects, Bz liked to be alone and quiet, closed, unable to put himself in various situations and away from the zone that maked him uncomfortable. Meanwhile, according to his friends Ry was a polite, helpful and kind person. In fact, his friends said that he was person who did not want to show his intelligence. For the subjects $\mathrm{Wd}$ and $\mathrm{Kl}$, it was said that they were arrogant. Kl was often ignorant and bullied his other friends. The social development of the subject's emotions was in line with the statement "they relate well to adults and may have problems playing with underprivileged friends" [10]. Related to the uniqueness of the language development of the subjects, the subjects of $\mathrm{Wd}, \mathrm{Kl}$ and Ry were more dominant and good in non-verbal language, and for their own verbal language there was no constraint. $\mathrm{Bz}$ would be fussy when there were things he did not like done by his friends, or when his privacy was disturbed. His vocabulary wa very broad and just like an adult child. Gifted children possess extensive vocabulary and use complex sentence structures, showcase talent in storytelling and tell it, ask wise questions, discuss issues and ideas, and create rich descriptions [11]. The uniqueness of the development of moral ethics of the four participants, they have developed like friends of their age. However, Ry showed that his moral ethics development was in higher level than his colleagues. On the other hand, Kl looked nosier compared to other friends. Gifted children are more sensitive to moral values and issues; understand "good behavior" and "bad behavior" early on. [9] They have a strong need for consistency between values and personal action [12]. Young gifted children often exhibit higher levels of maturity in one or more areas of development [13]. This maturity has been attributed to a number of intellectual skills, such as advanced verbal skills, high reading ability, high math skills, time perception, memory retention, and ongoing attention span[14]. Although gifted children may demonstrate a strong desire to master tasks and ask complex questions [15], high ability in one area may coexist with the usual ability in other formal identities, which is complicateds [16]. In addition, it appears that not all talented individuals exhibit the same behavior. Talented individuals are not a homogeneous group, and therefore, may exhibit these characteristics in varying degrees and intensities [17]. As a result of the 20-year study, Sandhu emphasizes that gifted individuals can exhibit different behaviors, and one talent is not at issue [18]. Although there are some developmental characteristics for gifted children to generalize and make them easy to realize, every gifted child is very special like the other kids [19].

\section{CONCLUSION}

Gifted children develop in extremely sensitive (extreme) conditions in some areas and are unique in every aspect of their development. Each gifted child has the uniqueness and distinction of every aspect of his development. Because gifted children are not a homogeneous group, although they likely exhibit some characteristic similarities. It is also revealed in the [17] study that the gifted children may have some of the same characteristics in many respects, yet they still have the uniqueness and differentiation of each other, therefore gifted children are not a homogeneous group. Observations show that the three children show different and unique developments of each aspect, not only from peers but also with each other.

\section{ACKNOWLEDGEMENT}

This article was created to take part in one of the LPDP Awardee Community agendas in the field of self-development. Thank you to the PWKTI committee for facilitating the articles of the LPDP UPI awardees to be included in the proceedings.

\section{REFERENCES}

[1] M. Neihart, S. Reis, N. Robinson, and E. Al., The Social and Emotional Development of Gifted Children: What do We Know? Waco: Prufrock Press, 2002.

[2] M. Neihart, L. Yeo, and (in Press), Psychological issues unique to the gifted student. In:Pfeiffer SI, Shaunessy-Dedrick E and Foley-Nicpon M (eds) Handobook on Giftedness and Talent Development. Washington: APA Books.

[3] A. Morawska and M. R. Sanders, "Parenting gifted and talented children: Conceptual and empirical foundations," Gift. Child Q., vol. 53, no. 3, pp. 163-173, 2009.

[4] A. Morawska and M. Sanders, "An evaluation of a behavioural parenting intervention for parents of gifted children," Behav. Res. Ther., vol. 47, no. 6, pp. 463-470, 2009.

[5] S. Pfeiffer, Serving the Gifted. Evidence-Based, Clinical and Psychoeducational Practice. New York: Routledge, 2013.

[6] A. Morawska and M. R. Sanders, "Parenting gifted and talented children: what are the key child behaviour and parenting issues?," Aust. N. Z. J. Psychiatry, vol. 42, no. 9, pp. 819-827, 2008.

[7] G. L. Fornia and M. W. Frame, "The social and emotional needs of gifted children: Implications for family counseling," Fam. J., vol. 9, no. 4, pp. 384-390, 2001.

[8] G. A. Davis, Anak berbakat dan pendidikan keberbakatan. Jakarta: Jakarta: PT Indeks, 2012.

[9] B. Clark, Growing up gifted: Developing the potential of children at home and at school (7th ed.). . Upper Saddle River,.NJ: Pearson Prentice Hall., 2008.

[10] G. Davis and S. Rimm, Education of the gifted and talented (5th ed.). Boston: Allyn \&Bacon, 2004.

[11] J. F. Smutny, S. Y. Walker, and E. A. Meckstroth, Teaching Young GiftedChildren in the Regular Classroom: Identifying, Nurturing, and Challenging Ages 4-9. Minneapolis, MN: Free Spirit Publishing Inc, 1997. 
[12] B. Clark, Growing up gifted (5th Ed. Columbus, OH.: Charles E. Merill, 2002.

[13] C. C. Kuo, J. Maker, F. L. Su, and C. Hu, "Identifying young gifted children and cultivating problem solving abilities and multiple intelligences," Learn. Individ. Differ., vol. 20, no. 4, pp. 365-379, 2010.

[14] L. Porter, Gifted young children: a guide for parents and teachers, 2nd edn. Crows Nest, NSW: Allen \&Unwin, 2005.

[15] E. Winner, "Giftedness: Current theory and research," Curr. Dir. Psychol. Sci., vol. 9, no. 5, pp. 153-156, 2000.

[16] M. K. Kitano, "A developmental model for identifying and serving young gifted children," Early Child Dev. Care, vol. 63, no. 1, pp. 19-31, 1990.
[17] J. . Smutny, Teaching young gifted children in the regular classroom. Eric Clearinghouse on Disabilities and Gifted Education Reston VA, Eric Digest E595. 2000.

[18] I. . Sandhu, "http://www.brainy child.com/expert/types-of giftedness.shtml.(Accessed date: 30.10.2017)," 2010.

[19] C. Gur, "The effect of art Education programme on the drawing skills of gifted six year-old children coming from upper socio- economic level. PhD thesis," Ankara, Turkey: Gazi University, Institute of Education Sciences., 2006. 